\title{
LEVELS OF PROINFLAMMATORY AND IMMUNOSUPPRESSIVE CYTOKINES IN PERIPHERAL BLOOD IN PHLEGMONOUS PERITONITIS PATIENTS
}

Introduction. Among surgical diseases, peritonitis is a life-threatening pathological condition characterized by inflammation at both local and systemic levels. Identifying proinflammatory mediators in peripheral blood and in peritoneal fluid and their quantitative characteristic is vital for the diagnosis. High levels of these mediators may be indicators of complications development or lethal outcome.

The aim of the study - to learn the levels of proinflammatory and suppressive cytokines in the peripheral blood and compare their properties in patients with acute phlegmonous appendicitis, which causes peritonitis.

Recearch Methods. The study measured levels of proinflammatory and suppressive cytokines in the peripheral blood and compare their properties in patients with acute phlegmonous appendicitis, which causes peritonitis. Blood samples from 90 patients with peritonitis and 98 healthy volunteers were analyzed. Blood cytokine content was determined using enzyme-linked immunosorbent assay (Vector-Best). Optical density was measured on an analyzer "Stat FAX 303 PLUS" (USA, pg/ml). The results of the study were statistically analyzed using parametrical and nonparametrical criteria using "Minitab 16" software. Colmogorov-Smirnov test was used to determine the differences between the group of patients and the control group. Key numerical data was gathered and compared using the $U$-criteria of Mann-Whitney, whereas the average of the two independent data sets were analyzed using the Student method. All persons who took part in the study gave their written consent as required by the bioethics committee.

Results and Discussion. The research demonstrated that acute inflammation during phlegmonous peritonitis is characterized by mediator synergy between proinflammatory and suppressive potentials of the immune response at the systemic level. Significant $(p<0.001)$ increase in the levels of proinflammatory $(I L-1 \beta, I L-6, T N F-\alpha)$ and suppressive (IL-10, TGF- $\beta$ ) cytokines in the peripheral blood was observed in patients with phlegmonous peritonitis.

Conclusions. Acute inflammation during phlegmonous peritonitis is characterized by mediator synergy between proinflammatory and suppressive potentials of the immune response at the systemic level. Moreover, significant $(p<0.001)$ increase in the levels of proinflammatory $(I L-1 \beta, I L-6, T N F-\alpha)$ and suppressive $(I L-10, T G F-\beta)$ cytokines in the peripheral blood was observed in patients with phlegmonous peritonitis.

KEY WORDS: peritonitis; cytokines IL-1 $\beta$, IL-6, IL-10, TNF- $\alpha$, TGF- $\beta$; inflammation.

INTRODUCTION. Among surgical diseases, peritonitis is a life-threatening pathological condition characterized by inflammation at both local and systemic levels [1]. Identifying proinflammatory mediators in peripheral blood and in peritoneal fluid and their quantitative characteristic is vital for the diagnosis. High levels of these mediators may be indicators of complications development or lethal outcome [2]. It has been demonstrated that bacterial peritonitis in mice lethal outcome was linked to increased levels of tumor necrosis factor $\alpha$ (TNF- $\alpha$ ), interleukin 6 (IL-6), and lower contents of IL-10 [3]. This study was conducted on 202 patients and severity of peritonitis was associated with increased levels of IL-6 $(p<0,025)$, TNF- $\alpha(p<0.01)$, CRP $(p<0.033)$, IL-10 $(p<0.0001)$ та IL-13 $(p<0.0001)$ (c) L. O. Kuyun, 2018.
[4]. According to another study that measured levels of IL-1, TNF- $\alpha$, IL-6, IL-10, IF-y in the serum and the peritoneal fluid in 66 patients with secondary peritonitis. Correlational analysis did not find a connection between the levels of cytokines in blood and peritoneal fluid. IL-10 level was considerably higher $(p=0.04)$ in patients without causing lethal outcome [5]. There is no definitive data on reciprocal connection between proinflammatory and suppressive cytokines in the peripheral blood during the development of peritonitis.

The aim of the study - to learn the levels of proinflammatory and suppressive cytokines in the peripheral blood and compare their properties in patients with acute phlegmonous appendicitis, which causes peritonitis. 
RECEARCH METHODS. The study included blood samples from 90 patients with peritonitis and 98 healthy volunteers. Blood cytokine content was determined using enzyme-linked immunosorbent assay (Vector-Best). Optical density was measured on an analyzer "Stat FAX 303 PLUS" (USA, pg/ml). The results of the study were statistically analyzed using parametrical and nonparametrical criteria using "Minitab 16" software. Colmogorov-Smirnov test was used to determine the differences between the group of patients and the control group. Key numerical data was gathered and compared using the U-criteria of Mann-Whitney, whereas the average of the two independent data sets were analyzed using the Student method. The average quantitative changes and root-meansquare values for parametrical methods and the median with 1 and 3 quartile for nonparametrical values are presented. All persons who took part in the study gave their written consent as required by the bioethics committee.

RESULTS AND DISCUSSION. The levels of proinflammatory cytokines in the peripheral blood in the control group and in peritonitis patients (Table 1).

The study results presented in Table 1 demonstrate that phlegmonous peritonitis patients diagnosed with surgical acute inflammation of the appendix exhibited increased activity of the inflammatory process at the systemic level. The content of IL1- $\beta$, IL- 6 and TNF- $\alpha$ in the peripheral blood (Table 1) was significantly higher $(p<0.001)$ than in the control group. Concentration of suppressive cytokines is shown in Table 2.

Table 1 - Proinflammatory cytokine levels in the peripheral blood in peritonitis patients (M $\pm S D$ )

\begin{tabular}{|l|c|c|c|}
\hline \multicolumn{1}{|c|}{ Parameters } & Control group $(\mathrm{n}=98)$ & Peritonitis $(\mathrm{n}=90)$ & $\mathrm{P}$ \\
\hline $\mathrm{IL} 1 \beta, \mathrm{pg} / \mathrm{ml}$ & $13.3 \pm 5.1$ & $122.4 \pm 29.3$ & $<0.001$ \\
\hline $\mathrm{IL}-6, \mathrm{pg} / \mathrm{ml}$ & $8.2 \pm 3.1$ & $99.5 \pm 25.9$ & $<0.001$ \\
\hline TNF- $\alpha, \mathrm{pg} / \mathrm{ml}$ & $26.1 \pm 7.6$ & $123.1 \pm 36.0$ & $<0.001$ \\
\hline
\end{tabular}

Note. $\mathrm{P}$ - validity of parameter differences between the group of patients and the control group.

Table 2 - Levels of suppressive cytokines in the peripheral blood during peritonitis (M $\pm \mathrm{SD}$ )

\begin{tabular}{|l|c|c|c|}
\hline \multicolumn{1}{|c|}{ Parameters } & Control group $(\mathrm{n}=98)$ & Peritonitis $(\mathrm{n}=90)$ & $\mathrm{P}$ \\
\hline IL-10, $\mathrm{pg} / \mathrm{ml}$ & $21.6 \pm 5.7$ & $144.3 \pm 34.9$ & $<0.001$ \\
\hline TGF- $\beta, \mathrm{pg} / \mathrm{ml}$ & $12.0 \pm 4.2$ & $66.9 \pm 21.3$ & $<0.001$ \\
\hline
\end{tabular}

Note. $\mathrm{P}$ - validity of parameter differences between the group of patents and the control group. Suppressive cytokine content during phlegmonous peritonitis (Table 2) was also significantly higher in surgical patients when compared with the parameters from the group of volunteers.

Our results demonstrated the presence of synergy between the proinflammatory and suppressive potentials of the immune response at the systemic level in patients during the development of acute phlegmonous peritonitis. Similar results were observed while studying cytokine levels in the peritoneal fluid in children with perforated appendicitis caused by acute phlegmonous peritonitis. The study demonstrated increased levels of TNF- $\alpha$ and IL-10 [6]. An experimental model of murine peritonitis showed that high levels of IL-6, IL-10, and TNF- $\alpha$ significantly $(p<0.0001)$ increased mortality rates in the experimental animals [7]. TAKEDA-143242 (TAK-242) - an experimental molecule that inhibits liposaccharide-induced intracellular signaling and inflammation. TAK-242 prevents release of TNF- $\alpha$, IL-1 $1 \beta$, and IL- 6 from the activated macrophages. An experimental peritonitis model conducted using pigs that were injected with TAK-242 showed that lower levels of proinflammatory cytokines were released. Moreover, the experimental treatment yielded lower mortality rates [8]. IL-10 is one of the lead anti-inflammatory cytokines necessary for regulation of excessive activity of proinflammatory cytokines and chemokines [9]. Another study has shown that IL-10 lowers the activity of macrophages through inhibiting production of $y$-interferon, IL-2, IL-12, and IL-18. Modulating the inflammatory response is essential for ensuring a balanced immune system [10]. Our study has shown that systemic inflammation during acute phlegmonous peritonitis is associated with increased levels of proinflammatory and suppressive cytokines in the peripheral blood. In our opinion, these results may be an indicator of suppressive activity of the immunocompetent cells despite high levels of the systemic inflammation in patients with phlegmonous peritonitis.

CONCLUSIONS. Acute inflammation during phlegmonous peritonitis is characterized by mediator synergy between proinflammatory and suppressive potentials of the immune response at the systemic level. Moreover, significant $(p<0.001)$ increase in the levels of proinflammatory (IL-1 $\beta$, IL-6, TNF- $\alpha$ ) and suppressive (IL-10, TGF- $\beta$ ) cytokines in the peripheral blood was observed in patients with phlegmonous peritonitis. 


\section{LITERATURE}

1. Antibiotics-first strategy for uncomplicated acute appendicitis in adults is associated with increased rates of peritonitis at surgery. A systematic review with metaanalysis of randomized controlled trials comparing appendectomy and non-operative management with antibiotics / M. Podda, N. Cillara, S. Di Saverio [et al.] // Surgeon. - 2017. - 15 (5). - P. 303-314.

2. Proinflammatory cytokines in peritonitis / D. C. Badiu, V. Paunescu, A. Aungurenci, D. Pasarica // J. Med. Life. - 2011. - 4 (2). - P. 158-162.

3. Poor outcome in bacterial peritonitis is associated with dysregulated microRNAs and an increased inflammatory response / R. E. Barnett, R. C. Keskey, J. M. Rao [et al.] // Surgery. - 2013. - 154 (3). - P. 521-527.

4. Bracho-Riquelme R. L. The grade-response relation between severity of peritonitis and serum cytokine concentrations explains Mannheim Peritonitis Index threshold / R. L. Bracho-Riquelme, M. A. Reyes-Romero, A. Torres-Valenzuela // Surg. Infect. (Larchmt). - 2010. 11 (4). - P. 379-386.

5. Local and systemic innate immune response to secondary human peritonitis / F. Riché, E. Gayat,
C. Collet [et al.] // Crit. Care. - 2013. - 17 (5). P. 201.

6. Peritonitis in childhood: clinical relevance of cytokines in the peritoneal exudates / F. M. Haecker, E. FaslerKan, C. Manasse [et al.] // Eur. J. Pediatr. Surg. - 2006. 16 (2). - P. 94-99.

7. Peritoneal cytokines predict mortality after surgical treatment of secondary peritonitis in the rat / T. Hendriks, R. P. Bleichrodt, R. M. Lomme [et al.] // J. Am. Coll. Surg. - 2010. - 211 (2). - P. 263-270.

8. TAKEDA-143242 increased survival via reduced cytokines in porcine peritonitis / R. D. Goldfarb, J. W. Ortegel, J. E. Parrillo [et al.] // J. Surg. Res. - 2011. - 166 (2). P. 165-173.

9. Dual role of interleukin-10 in the regulation of respiratory syncitial virus (RSV)-induced lung inflammation / L. Sun, T. T. Cornell, A. LeVine [et al.] // Clin. Exp. Immunol. - 2013. - 172. - P. 263-279.

10. Interleukin 10 overexpression alters survival in the setting of gram-negative pneumonia following lung contusion / V. A. Dolgachev, B. Yu. Sun L, T. P. Shanley [et al.] // Shock. - 2014. - 41. - P. 301-310.

\section{REFERENCES}

1. Podda, M., Cillara, N., Di Saverio, S., Lai, A., Fero, ci F., ... Luidiana, G. (2017). Antibiotics-first strategy for uncomplicated acute appendicitis in adults is associated with increased rates of peritonitis appendectomy surgery. A systematic review with meta-analysis of randomized controlled trials comparing appendectomy and non-operative management with. Surgeon, 15 (5), 303314.

2. Badiu, D.C., Paunescu, V., Aungurenci, A. \& Pasarica, D. (2011). Proinflammatory cytokines in peritonitis. Dual role of interleukin-10 in the regulation of respiratory syncitial virus (RSV)-induced lung inflammation. J. Med. Life, 4 (2), 152-162.

3. Barnet, R.E., Kesley, R.C., Rao, J.M., Billeter, A.T., Kanaan, Z. \& Cheadle, W.G. (2013). Poor outcome in bacterial is associated with dysregulated microRNAs and an increased inflammatory response. Surgery, 154 (3), 521-527.

4. Branco-Riquelme, R.L., Reyes-Romero, M.A. \& Torres-Valenzuela, A. (2010). The grade-response relation between severity of peritonitis and serum cytokine concentrations explains Mannheim Peritonitis Index threshold. Surg. Infect. (Larchmt), 11 (4), 379-386.

5. Riché, F., Gayat, E., Collet, C., Mateo, J., Laisne, M.J. \& Launay, J.M. (2013). Local and systemic innate immune response to secondary human peritonitis. Crit. Care, 17 (5), 201.

6. Haeker False- Kan, E., Manasse, C.B., Hertel, R. \& von Schweinitz, D. (2006). Peritonitis in childhood: relevance of cytokines in peritoneal exudates. Eur. J. Pediatr. Surg., 16 (2), 94-99.

7. Hendricks, T., Bleichrodt, R.P., Lomme, R.M., De Man, B.M., van Goor, H.O. \& Buyner, O.R. (2010). Peritoneal cytokines predict after surgical treatment of secondary peritonitis in the rat. J. Am. Coll. Surg., 11 (2), 263-270.

8. Goldfarb, R.D., Ortegel, J.W., Parillo, J.E., Zanotti-Cavazzoni, S., Casey, L.C. \& Dellinger R.P. (2011). TAKEDA-143242 increased survival via reduced cytokines in porcine peritonitis. J. Surg. Res., 16 (20), 65-73.

9. Sun, L., Cornell, T.T., LeVine, A., Berlin, A.A., Hinkovska-Galcheva, V. \& Fleszar, A.J. (2013). Dual role of interleukine-10 in the regulation of respiratory syncytial virus (RSV)-induced lung inflammation. Clin. Exp. Immunol., 172, 263-279.

10. Dolgachev, V.A., Sun L, Yu.B., Shanley, T.P., Raghavendrun, K. \& Hemmila, M.R. (2014). Interleukin 10 overexpression alters survival in the setting of gramnegative pneumonia following lung contusion. Shock, 41, 301-310. 


\section{РІВНІ ПРОЗАПАЛЬНИХ ТА СУПРЕСИВНИХ ЦИТОКІНІВ У ПЕРИФЕРИЧНІЙ КРОВІ ХВОРИХ НА ФЛЕГМОНОЗНИЙ ПЕРИТОНІТ}

\section{Резюме}

Вступ. Серед хірургічних захворювань перитоніт є однією з найбільш небезпечних для життя патологій та характеризується запаленням як на місцевому, так і на системному рівнях. Визначення медіаторів запалення в перифреричній крові й перитонеальній рідині та їх кількісні показники життєво важливі в діагностиці цього захворювання. Високі рівні даних медіаторів особливо важливі для визначення наявності ускладнень, особливо з летальним завершенням хвороби.

Мета дослідження - вивчити рівні прозапальних і супресивних цитокінів у периферичній крові хворих та їх порівняльну характеристику в пацієнтів із серозно-фрібринозним перитонітом.

Методи дослідження. У дослідженні було використано матеріал, одержаний від 90 пацієнтів із серозно-фрібринозним перитонітом. Контрольна група складалася з 98 практично здорових осіб (волонтерів). Від усіх пацієнтів та волонтерів отримано добровільну письмову згоду на участь у науковому дослідженні, на яке є дозвіл комісії з біоетики. Вміст цитокінів у периферичній крові досліджували імуноферментним методом з використанням реактивів "Вектор-Бест". Оптичну щільність визначали на аналізаторі STAT FAX 303 PLUS (США). Концентрацію виражали в пк/мл. Усі отримані результати було піддано статистичній обробці для параметричних та непараметричних критеріїв із застосуванням програми мinitab 16. Для аналізу перевірки розподілу на нормальність використовували тест Колмогорова - Смірнова. Порівнювали центральні тенденції двох незалежних вибірок із застосуванням U-критерію Манна - Уітні й дві незалежні вибірки з використанням критерію Стьюдента.

Результати й обговорення. Встановлено, що вміст ІЛ-1 $\beta$, ІЛ-6 та ФНП- $\alpha$ в периферичній крові хворих на фрлегмонозний апендицит був значно більшим $(p<0,001)$ від значень аналогічних прозапальних цитокінів у контрольній групі. Рівень супресивних цитокінів при перитоніті також значно підвищувався і концентрація ІЛ-10 й ТФР- $\beta$ достовірно зростала порівняно з аналогічними показниками контрольної групи. Отримані дані свідчать про наявність синергізму в дії прозапальних та супресивних цитокінів при імунній відповіді на системному рівні у хворих у динаміці розвитку гострого фрлегмонозного апендиuumy.

Висновки. Гостре запалення при фрлегмонозному перитоніті характеризується синергізмом у діi прозапальних та супресивних цитокінів у хворих на перитоніт при імунній відповіді на системному рівні (в перифреричній крові). Також значно збільшується кількість ( $p<0,001)$ прозапальних (ІЛ-1 $\beta$, ІЛ-6, ФНП- $\alpha)$ та супресивних (ІЛ-10, ТФР-ß) цитокінів у перифреричній крові пацієнтів з фрлегмонозним перитонітом.

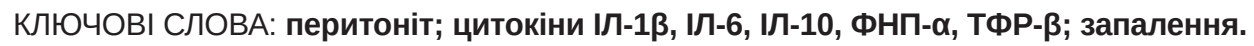

\section{УРОВНИ ПРОВОСПАЛИТЕЛЬНЫХ И СУПРЕССИВНЫХ ЦИТОКИНОВ В ПЕРИФЕРИЧЕСКОЙ КРОВИ БОЛЬНЫХ ФЛЕГМОНОЗНЫМ ПЕРИТОНИТОМ}

\section{Резюме}

Вступление. Среди хирургических заболеваний перитонит является одной из наиболее опасных для жизни патологий и характеризуется воспалением как на локальном, так и на системном уровнях. Определение медиаторов воспаления в перифрерической крови и перитонеальной жидкости и их количественные показатели жизненно важны в диагностике этого заболевания. Высокие уровни данных медиаторов особенно важны для определения наличия осложнений, особенно с летальным завершением болезни.

Цель исследования - изучить уровни провоспалительных и супрессивных цитокинов в перифрерической крови больных и их сравнительную характеристику у пациентов с серозно-фрибринозным перитонитом. 
Методы исследования. В исследовании было использовано материал, полученный от 90 пациентов с серозно-фрибринозным перитонитом. Контрольная группа состояла из 98 практически здоровых лиц (волонтеров). От всех пациентов и волонтеров получено добровольное письменное согласие на участие в научном исследовании, на которое есть разрешение комиссии по биоэтике. Содержание цитокинов в перифрерической крови исследовали иммунофрерментным методом с использованием реактивов "Вектор-Бест". Оптическую плотность определяли на анализаторе STAT FAX 303 PLUS (CША). Концентрацию выражали в пг/мл. Все полученные результаты были подвержены статистической обработке для параметрических и непараметрических критериев с применением программы Minitab 16. Для анализа проверки распределения на нормальность использовали тест Колмогорова - Смирнова. Сравнивали центральные тенденции двух независимых выборок с применением U-критерия Манна - Уитни и две независимые выборки с использованием критерия Стьюдента.

Результаты и обсуждение. Установлено, что содержание ИЛ-1ß, иЛ-6 и ФНО- $\alpha$ в периферической крови больных фллегмонозным аппендицитом было значительно больше $(p<0,001)$ от значений аналогичных провоспалительных цитокинов в контрольной группе. Уровень супрессивных цитокинов при перитоните также значительно повышался и концентрация ИЛ-10 и ТФР- $\beta$ достоверно возрастала по сравнению с аналогичными показателями контрольной группы. Полученные данные свидетельствуют о наличии синергизма в действии провоспалительных и супрессивных цитокинов при иммунном ответе на системном уровне у больных в динамике развития острого фрлегмонозного аппендицита.

Выводы. Острое воспаление при фрлегмонозном перитоните характеризуется синергизмом в действии провоспалительных и супрессивных цитокинов у больных перитонитом при иммунном ответе на системном уровне (в перифрерической крови). Также значительно увеличивается количество $(p<0,001)$

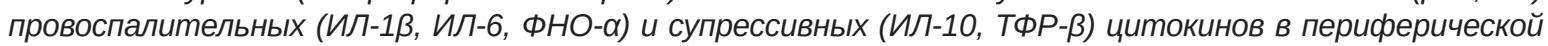
крови пациентов с фрлегмонозным перитонитом.

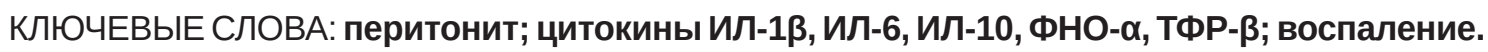

Received 27.09.18

Address for correspondence: L. O. Kuyun, O. Bohomolets National Medical University, Taras Shevchenko boulevard 13, Kyiv, 01601, Ukraine, e-mail: Iudaalex@ukr.net. 